\title{
Increasing Educational Equity through the Principals' Partnership Program in Talaud Island
}

\author{
Widowati Pusporini $^{1,2, *}$, Ari Setiawan ${ }^{2}$, Estri Oktarena Ikrarini ${ }^{3}$ \\ ${ }^{1}$ Program Pascasarjana, Universitas Negeri Yogyakarta, Indonesia \\ ${ }^{2}$ Program Pascasarjana Pendidikan, Universitas Sarjanawiyata Tamansiswa, Indonesia \\ ${ }^{3}$ Fakultas Keguruan dan Ilmu Pendidikan, Universitas Sarjanawiyata Tamansiswa, Indonesia
}

Received July 13, 2019; Revised September 9, 2019; Accepted September 24, 2019

Copyright $\subseteq 2019$ by authors, all rights reserved. Authors agree that this article remains permanently open access under the terms of the Creative Commons Attribution License 4.0 International License

\begin{abstract}
This article addresses achievements in three aspects gained by school principals as the main target of a partnership program, i.e. curriculum management, academic supervision, and entrepreneurship development. The data were collected in a six-month period as a result of the mentoring process of the school principals and their facilitators by conducting intervening mentoring process. The qualitative data were collected from the implementation of an action plan and were analyzed by using the fishbone diagram in order to reveal some main related factors to achieve their essential elements. The findings show that those three aspects being assessed in this study experienced a positive trend to those of eight school principals by establishing $8.88 \%$ level of improvement - from the initial mentoring stage (83.5\%) to the second mentoring stage of $92.38 \%$.
\end{abstract}

Keywords Equity of Education, Partnership, Indonesia, Talaud

\section{Introduction}

Indonesia, consisting of 17,054 separated islands, faced a great challenge due to its geographical barrier in providing equal quality of education; as what was represented by Talaud Island, an island in the Region of, Province of North Sulawesi. Diversities and disparities emerged in terms of access, quality, relevance, and competitiveness shown by well-established schools located in Javanese island and the less-established ones located mostly in other islands. The problems appeared not only on how they attempted to meet the national standards as well as some other external criteria, but also on how they put some efforts in three principle components - Curriculum management, Academic supervision, and management of school ecosystem [1].

The results of Analytical and Capacity Development Partnership of Indonesian Education Ministry revealed that the lowest competency of school principals is the competency for supervising and using Information Technology (IT) in their management and for teaching and learning purposes. Principals of public schools claimed that their competence was higher than that of Islamic school principals in terms of managerial, entrepreneurship, supervision, as well as Teaching and Counseling - the gap was, indeed, statistically significant. Moreover, female principals of both public and Islamic schools asserted that their competence level was lower than those of male principals in relation to managerial, entrepreneurship, and supervision. The levels of the school principals' qualifications, grades of school accreditation, school status (state or private schools), and location services as significant variables related to managerial, entrepreneurship, supervision, as well as Teaching and Counseling competences. Whereas, at most indicators of competence, the principals of schools located at rural or remote areas claimed that their competences were lower than those of the school's principals from urban or semi-urban areas [2].

As indicated by the research of the Education Ministry, a gap due to the unequal competence qualities has existed among school principals in Indonesia. This research, therefore, is expected to act as a reference and an additional information to similar researches for improving the process of evaluation and implementation of such a program. According to the Government Regulation number 78 the year 2014, the term Underdeveloped Regions refers to any regions in which both the areas and communities are less developed than other regions based on the national scale.

The partnership program is one among the primary programs conducted by The Ministry of Education that has been existed since 2015 . This program is held by pairing 
chief partners and school principals in the mentoring process on the development of education quality administered in induced schools. The facilitators of this program act as facilitating the processes and also ensuring that all activities are in line with the plan made by the Ministry. The relation between the three of them can be seen in the following figure.

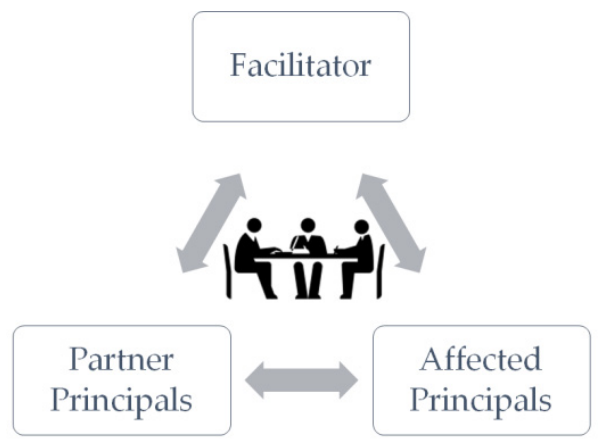

Figure 1. Relation of Facilitator, Partner Principals, and Affected Principals

This article illustrates three achievements as the main target of the partnership program, i.e. curriculum management, academic supervision, and entrepreneurship development. The data were collected during the implementation of the Job Learning partnership program addressed for six state school principals in Talaud.

This study was able to reveal the actual results of the partnership program in 2018 held in Talaud island, Province of North Sulawesi. This article, thus, is expected to be a reference of similar fields related to partnership program for school principals, its mechanism, as well as the benefits of conducting such program.

Theoretically, a school principal is able to be both administrator and manager [3-5]. This idea is supported by Branch, Hanushek, and Rivkin [6] stating that the leading position in a school is its principal as he becomes the key in determining the success of the school. Therefore, it is essential to regulate minimal competency that should be possessed by a school principal, along with its main tasks. A principal should also play a significant role; he is also required to possess prominent managerial skills that enable him to meet both academic and non-academic requirements.

A school principal, therefore, works as an educator, manager, administrator, supervisor, innovator, and motivator. Principles confirm that as an educator, a principal must be able to formulate strategies on how to improve his teachers' professionalism; as he teaches his students (as stated by the law that a school principal is indeed a teacher), he also educates his management personnel (school teachers and staffs) to optimize their works at school [7]. They need to create a conducive situation, give advice to others, support their education staffs, and give motivation to all teachers by monitoring them so that they are able to conduct attractive learning models supportive to the students' characteristics. As a manager, a school principal should also have strategies on how to apply the functions of management in both effective and efficient ways; thus, a good competence in both academic and non-academic levels is highly essential. Accordingly, a managerial skill becomes an important element of a school's success.

Prior to this research, research about teacher partnership found that such model brought some significant influences to both teachers and school principals in optimizing their competencies to improve the quality of education in elementary level [8]. This led to the improvement of education quality within that area. Armstrong also mentioned similar research addressing the School for Partnership School program carried out by the Ministry of Education of England [9]. The results of the research showed that the program improved the competencies and created better career opportunities to the school staffs, provided opportunities to schools to share their innovations and best practices, reduced the tasks of school principals, and eventually, made some efficiency in the schools' organization and finance.

Chapman also affirmed that the result of partnership program is to equalize the quality of education, to develop the school's capacity, and to increase the local authority to create positive changes including the principals' leadership, developing teachers' knowledge, and to increase teacher's understanding on evaluation and on increasing the learners' aspiration [10].

\section{Research Methods}

The data of this study were collected by combining quantitative and qualitative approaches. In this article, the qualitative approach was to support the quantitative one. The quantitative data were obtained by using a set of instruments consisting of a questionnaire and knowledge mapping test by using the web. The questionnaire and mapping test consists of three competencies (management, academic supervision, and entrepreneurship) listing 9 items for the questionnaire and 50 items for the mapping test.

The qualitative data were collected by conducting observation and interview with school principals as the respondents. The data were gathered within six months during the partnership process among affected principals, partner principal, and facilitators, starting from April to September 2018. During the On the Job Learning program conducted at affected schools, both school principals and facilitators executed not only the intervening partnership but also implemented the action plan. It was to certify that those qualitative data collected during the implementation of the action plan were valid as they were prepared to be analyzed by using triangulation. They were, then, compared and contrasted to other qualitative data taken 
during the interviews, observations, document studies, and focus group discussions at those affected schools.

After all, data were already analyzed, the analysis was continued by using the fishbone diagram to reveal the primary constituents of each factor, i.e., Man, Tools, Method, Material, Measurement, and Environment. The next step was conducting measurement by using a Likert scale to gain quantitative result from the existed factors. All those analyzes were essential to finding appropriate solutions against each problem.

\section{Results}

The instruments of School Principals Partnership Program 2018 had three main components formulated into 140 task items: Curriculum Management consisted of 68 items; Academic Supervision divided into 32 items, and School Ecosystem Management composed of 40 items. The data showed that in 106 documents collected from the affected schools, there were approximately $7-9$ items completed by each affected school; and in sum, 17 task items could be completed from those of 140. Consequently, it should be well noted that unlisted task items from every affected school were those assumed as being good categories. The principals were then required to ensure how those indicators that were not listed on their action plan could improve persistently.

The following table and chart summarize the percentage of aggregate number achieved during the School Principals Partnership Program in 2018, especially one held in Talaud region involving eight school principals from three different islands as parts of the region.

The data show increasing achievements performed by participants of the partnership program as represented by higher points achieved in the second mentoring compared to the first one. The rising trend appears in all three aspects of the principal partnership program. However, Julce was considered to perform at the lowest improvement as his scores were fixed at 100 points. The following chart shows the different trends of those principals.

Table 1. Summary of achievements in three components of School Principal Partnership Program 2018 in Talaud Region

\begin{tabular}{|c|c|c|c|c|c|}
\hline No. & Name & $1^{\text {st }}$ Mentoring & Percentage (\%) & $2^{\text {nd }}$ Mentoring & Percentage (\%) \\
\hline 1 & Sinyo & 99 & $70,7 \%$ & 100 & $71,4 \%$ \\
\hline 2 & Julce & 100 & $71,4 \%$ & 100 & $71,4 \%$ \\
\hline 3 & Pelma & 80 & $57,1 \%$ & 90 & $64,3 \%$ \\
\hline 4 & Bebby & 71 & $50,7 \%$ & 78 & $55,7 \%$ \\
\hline 5 & Tri & 90 & $64,3 \%$ & 94 & $67,1 \%$ \\
\hline 6 & Lijwen & 89 & $63,6 \%$ & 96 & $68,6 \%$ \\
\hline 7 & Adriana & 77 & $55 \%$ & 92 & $65,7 \%$ \\
\hline 8 & Yudhita & 62 & $44,3 \%$ & 89 & $63,6 \%$ \\
\hline
\end{tabular}

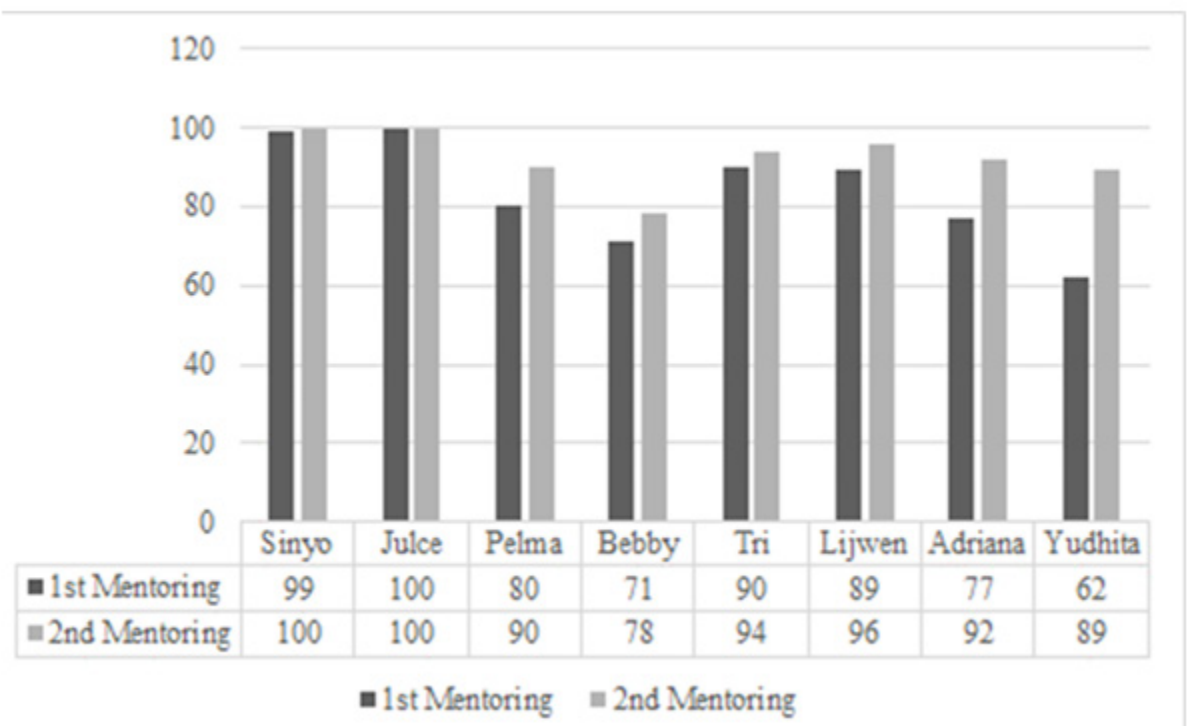

Figure 2. Comparison of achievements in three components among the school principals of Talaud 
Table 2. Structural Equation Model of the 3 primary factors

\begin{tabular}{|c|c|c|c|c|c|}
\hline No & School Principal & Curriculum Management & Academic Supervision & Entrepreneurship Development & Average \\
\hline 1 & Sinyo & $70 \%$ & $84 \%$ & $75 \%$ & $76.3 \%$ \\
\hline 2 & Julce & $81 \%$ & $66 \%$ & $78 \%$ & $75.0 \%$ \\
\hline 3 & Pelma & $87 \%$ & $75 \%$ & $74 \%$ & $78.7 \%$ \\
\hline 4 & Bebby & $65 \%$ & $77 \%$ & $86 \%$ & $76.0 \%$ \\
\hline 5 & Tri & $73 \%$ & $86 \%$ & $80 \%$ & $79.7 \%$ \\
\hline 6 & Lijwen & $78 \%$ & $83 \%$ & $82 \%$ & $81.0 \%$ \\
\hline 7 & Adriana & $76 \%$ & $81 \%$ & $90 \%$ & $82.3 \%$ \\
\hline 8 & Yudhita & $84 \%$ & $64 \%$ & $78 \%$ & $75.3 \%$ \\
\hline
\end{tabular}

Having measured the results of the first and second mentoring, it can be seen that Yudhita (one of the principals) reached the most significant achievement from the improvement in the second mentoring process by gaining 27 points.

In addition, to complete the results of this study, it is necessary to distribute questionnaires to students of each affected school to identify their interest level and opinions regarding their learning process at school. The questionnaire was intended to promote better quality in improving educational equity. The questionnaires were distributed to students of affected schools only for this study's purpose. Each school was given 30 questionnaires that should be answered by its students; thus, about 240 responses could be gathered from all those eight schools. Those responses were, then, classified as total answers to serve as factors covering three primary factors, i.e., curriculum management, academic supervision, and entrepreneurship development. The classification related to those three factors in each school can be summarized as follows.

The average scores represent the education quality levels of eight schools gained through the mentoring process. The score of each factor was also analyzed for finding the relation between the factors and their causes to improve the education quality. Such a relation can be observed in the following diagram.

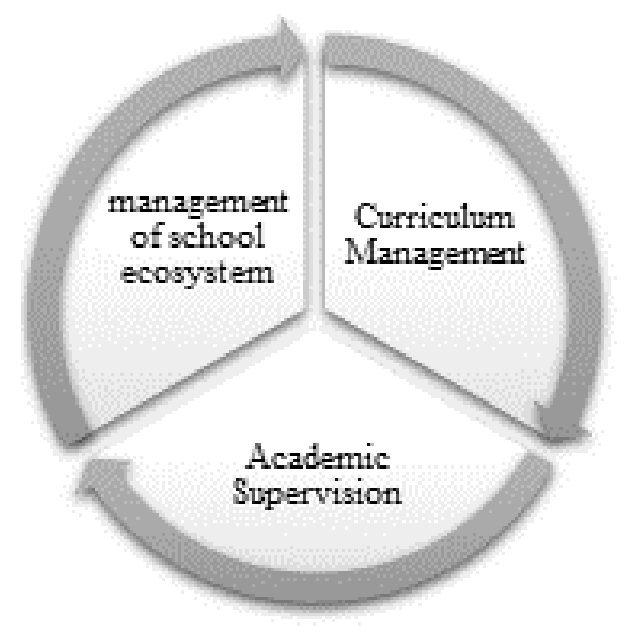

Figures 3. The relation between factors to improve the education quality

The following fishbone diagram was used to conduct further analysis on the primary factors as the focus in enhancing the education quality in each school. The diagram also presents the relevance of those three primary factors in relation to the causes. 


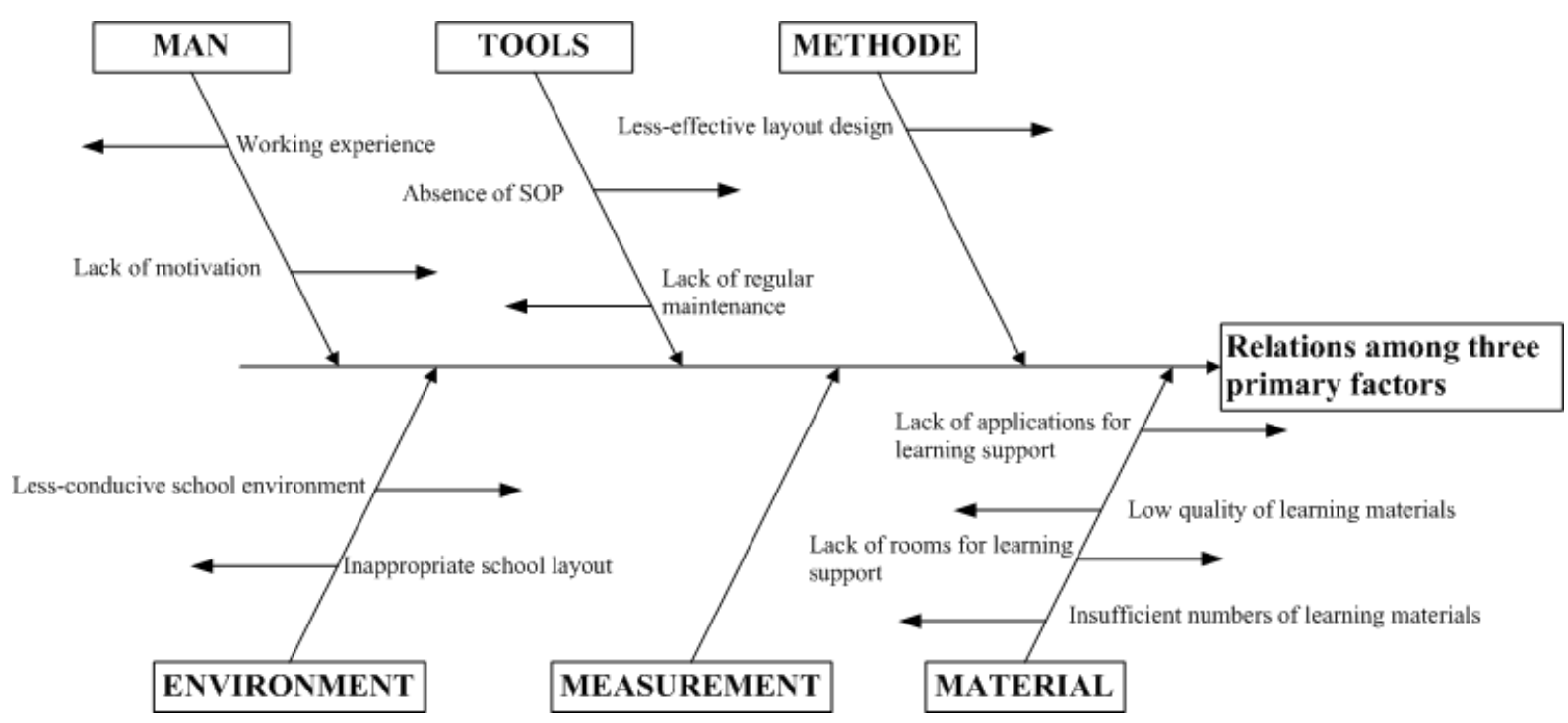

Figure 4. Fishbone Diagram of causes in the relation among three primary factors

The fishbone diagram illustrates that measurement using a Likert scale was necessary to gain qualitative results by contrasting a factor to other factors. It was likely to find out that the Man factor contributes $18 \%$ of influence towards the improvement of school quality, similar to that of the Tools and Environment factors. The Method gained 9\% in supporting the school quality enhancement; while the Material factor gave the highest contribution (36\%) to the improvement of school quality. Therefore, it can be proposed that the material becomes the most influential factor that should be prioritized. Nevertheless, other contributing factors may also be refined to reach the most excellent quality of education provided.

\section{Discussion}

The collaboration of school partnership showed positive results in areas of students achievement, potential development of both teachers and school, and some efficiency. According to Ertmer and Hruskocy, a collaboration developed during a school partnership may increase teachers' ability in conducting their teaching-learning process related to their instructional skill, the use of new learning methods, students' confidence, students' self-efficacy, and the use of technology in a teaching-learning process by both teachers and students. They also stated that a school partnership program carried out in elementary schools could support their optimized development of the educational process [11]. Furthermore, a society partnership is also a method for promoting cooperation among parents, society, and school.

Those findings were in accordance with the results gained during the principals' partnership program in Talaud region. All data displayed positive improvements in achieving all tasks required during the program involving school management, academic supervision, and entrepreneurship.

This study, therefore, was able to expose the three primary aspects of the school partnership program held in Talaud by gaining satisfying results. During the first mentoring process, the average score of all participants in the perspective of three different aspects (managerial, supervision, and entrepreneurship) reached $83.5 \%$; the score was even higher to $92.38 \%$ in the second period. It shows that this program is capable of improving their achievements up to $10 \%$ from its initial result.

\section{Conclusions}

Significant progress demonstrated in several aspects of partnership appeared as a result of significant commitments and efforts of those school principals despite any geographical barriers in Talaud island, including other challenges such as difficulties in information access and lack of its human resources' capabilities. Thus, it is highly recommended that other further researches can be conducted by collecting data from any schools involved in the partnership program held throughout Indonesia to demonstrate the success of their school principals and the program itself.

\section{REFERENCES}

[1] Kemdikbud, Technical Guide to for school principals partnership Facilitator. Jakarta, 2017.

[2] Kemdikbud, "Basic Study on Competency of Principal's Madrasah/School Supervisor, Partnership Program for Capacity Development and Education Analysis (ACDP), Jakarta, 2013.

[3] T. L. Drake and W. H. Roe, The principalship. Ohio USA: 
Merrill/Prentice Hall, 1986.

[4] Kompri, School Management: School's self-reliance orientation. Yogyakarta: Pustaka Pelajar, 2015.

[5] K. Banoglu, "School principals' technology leadership competency and technology coordinators," Educational Sciences-Theory and Practice, vol. 11, pp. 208-213, 2011.

[6] G. F. Branch, E. A. Hanushek, and S. G. Rivkin, "School leaders matter," Education Next, vol. 13, 2013.

[7] L. Yuliana, "The role of the principal as a supervisor in maturity of professional teachers," Jurnal Manajemen Pendidikan, vol. 3, 2007.

[8] Rokhmaniyah, "Optimizing the competency of educators and education professionals to improve education services through partnership Model," ed: Universitas Sebelas Maret, 2016.

[9] P. Armstrong, "Effective school partnerships and collaboration for school improvement: a review of the evidence," Department for Education, United Kingdom2015.

[10] C. Chapman, K. Lowden, H. Chestnutt, S. Hall, S. McKinney, M. Hulme, et al., "The school improvement partnership program: using collaboration and inquiry to tackle educational inequity," Robert Owen Centre for Educational Change, Scotland, 2015.

[11] P. A. Ertmer and C. Hruskocy, "Impacts of a university-elementary school partnership designed to support technology integration," Educational Technology Research and Development, vol. 47, pp. 81-96, 1999.

[12] I. Gurlui, "Educational partnership in primary education," Procedia-Social and Behavioral Sciences, vol. 180, pp. 606-611, 2015. 